\title{
Weed flora of aerobic rice and their effect on growth, yield and nutrient uptake by rice Oryza sativa in the coastal region of Karaikal of Puducherry, India
}

\author{
M. Pavithra* and R. Poonguzhalan \\ Department of Agronomy, Pandit Jawaharlal Nehru College of Agriculture and Research Institute, Karaikal, \\ Puducherry-609603, INDIA \\ *Corresponding author. E-mail: pavimuthukumar@gmail.com
}

Received: October 9, 2017; Revised received: November 6, 2017; Accepted: February 13, 2018

\begin{abstract}
A field experiment was conducted at farm lands of Pandit Jawaharlal Nehru College of Agriculture and Research Institute, Karaikal to know the weed floristic composition and their effect on growth, yield and nutrient uptake by aerobic rice (Oryza sativa). The results revealed that totally 29 species of weeds from 22 genera belonging to 17 families were noticed. Among them, four were grasses, six were sedges, and nineteen were broad leaved weeds. Of this 29 species, four were perennials, and the rest were annuals. During initial stages (30 DAS), sedges dominated (38.3\%) whereas at later stages (60 DAS) broad leaved weeds dominated the aerobic rice fields (42.5\%). Grasses were found to be comparatively less dominant at both the stages. Echinochloa colona Link. (28.1\%) followed by E. cruss-galli (L.) Beauv. (6.1\%) among the grasses; Cyperus difformis L. (19.8\%) followed by C. iria L $(9.9 \%)$ among the sedges and Ludwigia abyssinica $(28.0 \%)$ among the broad leaved weeds, were the predominant weed species in aerobic rice cultivation. Weeds, when left unchecked, competed with rice for all resources like nutrients, space, light and soil moisture. The unweeded control recorded the maximum nutrient depletion by weeds (76.6, 6.4 and $106.8 \mathrm{Kg}$ of $\mathrm{N}, \mathrm{P}$ andK ha ${ }^{-1}$ ). Due to severe competition, weeds suppressed the growth of rice which resulted in lower growth and yield attributes leading to lower grain (333 kg ha-1) and straw yields (1903 kg ha-1).
\end{abstract}

Keywords: Aerobic rice, Nutrient uptake, Weed flora, Yield

\section{INTRODUCTION}

Aerobic rice system has been evolved as the most promising water saving technology in rice culture wherein the crop is established via direct seeding in non-puddled and non-flooded fields (Mahajan et al., 2009). Rice cultivation using this system can save about 50 to $60 \%$ irrigation water and increase the water productivity by around $200 \%$ as compared to lowland flooded system (Bouman et al., 2002). Apart from less water requirement, aerobic rice demands fewer labours (Ho et al., 2000), capital input (Singh et al., 2008) which in turn minimizes production cost to great extent (Mann et al., 2007) and saves 29\% of the total cost of rice production (Ho et al., 2000). Due to all these, aerobic rice is expected to occupy $10-15 \%$ of the total rice area in India (Pasha et al., 2011).

Although aerobic rice system has huge potential as a water-wise technology, its adoption has been impeded by serious weed problem since both weed and crop seeds emerge at the same time and compete with each other for nutrients, light, space and moisture throughout the growing season resulting in less grain yield. Apart from this, there is also no water layer to suppress weed growth. So, weeds grow quickly in direct seeded aerobic rice as compared to transplanted flooded rice (Kamoshita et al., 2010). In aerobic rice system, the dry tillage practices and aerobic soil conditions are highly conducive for germination and growth of weeds which results in higher weed pressure coupled with greater grain yield losses as compared to flooded rice (Mahajan et al., 2009).

Rice grain production in India suffers a yearly loss of $15 \mathrm{mt}$ due to weed competition. Sipaseuth et al. (2000) reported that when weed control was optimum, and crop establishment was good, yields of direct-seeded rice could be equal to those of transplanted crop. A weed-free period for the first 30 to 45 days after sowing (DAS) is required to avoid any loss in yield because the dry weight of weeds increases greatly from 30 DAS in dry direct-seeded rice. Uncontrolled weeds reduce the yield by $96 \%$ and even up to $100 \%$ in dry direct-seeded rice (Maity and Mukherjee, 2008). Therefore, developing an effective weed management approach has been a challenge for widespread adoption of aerobic rice technology. It is essential to know the species composition of weed flora and their life forms in order to identify a suitable method for managing weeds. Hence, this study was undertaken to analyze 
the weed flora associated with aerobic rice and also to study the effect of weeds on growth, yield and nutrient uptake by aerobic rice in the coastal region of Karaikal, Union Territory of Puducherry, India.

\section{MATERIALS AND METHODS}

A field experiment was conducted during Rabi (September) 2013 in the farm lands of Pandit Jawaharlal Nehru College of Agriculture and Research Institute, Karaikal, Puducherry. The experimental site is situated $10^{\circ} 25^{\prime}$ North latitude and $79^{\circ} 49^{\prime}$ East longitude at an altitude of $4 \mathrm{~m}$ above the mean sea level. The soil of the experimental site was loamy sand in texture with alkaline $\mathrm{pH}(8.2)$. The soil was low in available nitrogen $\left(60.6 \mathrm{~kg} \mathrm{ha}^{-1}\right)$ and phosphorus (10.5 $\left.\mathrm{kg} \mathrm{ha}^{-1}\right)$ and medium in available potassium (184.4 $\mathrm{kg}$ $\left.\mathrm{ha}^{-1}\right)$. A total rainfall of $597 \mathrm{~mm}$ was received during the cropping period against the normal rainfall of 1022 $\mathrm{mm}$. The rainfall received during the cropping period was less and unevenly distributed. A medium duration (135 days) rice cv. 'ADT(R) 46' was sown on September 5,2013 , and the recommended package of practices for aerobic rice was followed. The seeds were sown by opening shallow furrows at $20 \mathrm{~cm}$ interval with the help of sickle and dibbling two or three seeds in each hill at $10 \mathrm{~cm}$ spacing. Later, the seeds were covered with soil. The recommended dose of fertilizers (150:50:50 Kg N: $\mathrm{P}_{2} \mathrm{O}_{5}: \mathrm{K}_{2} \mathrm{O}$ ha $^{-1}$ ) was applied. Twenty-five per cent of nitrogen, potassium and a full dose of phosphorus was applied at the time of sowing in the form of urea, muriate of potash and single super phosphate, respectively. The remaining quantity of nitrogen and potassium was applied in three equal splits at 30 (seedling), 60 (active tillering) and 90 DAS (flowering). The field was irrigated immediately after sowing, third day (life irrigation) and kept moist during the cropping period without maintaining a standing water condition.

Observations on weeds were recorded with the help of a $0.25 \mathrm{~m}^{2}$ quadrate placed randomly in the sampling area of each plot. Weeds falling within the frames of quadrat were counted, recorded and mean values are expressed in number $\mathrm{m}^{-2}$. After observing weed density, the weeds were removed, oven dried at $70^{\circ} \mathrm{C}$ for 72 hours and the dry weight was recorded and expressed in $\mathrm{g} \mathrm{m}^{-2}$. The data on weed flora, absolute density, relative density and dry weight were recorded at 30 and 60 days after seeding (DAS). The growth and yield attributes of rice were recorded by following the standard procedures. The crop from the net plot area was harvested on January 20, 2014, threshed and sundried. The grain and straw yields were recorded and expressed in $\mathrm{Kg} \mathrm{ha}^{-1}$. Nutrient removal by rice and nutrient depletion by weeds were estimated by adopting the standard analytical procedures. The nitrogen content in the digested grain, straw and weed samples was estimated by Micro Kjeldhal method (Jackson, 1973) and expressed in percentage on dry weight basis. The phosphorus and potassium content of the tri-acid digested grain, straw and weed samples were determined by Vanadomolybdo phosphoric yellow colour method in the HNO3 acid system and by Flame photometric method as described by Jackson (1973); and expressed in percentage on dry weight basis.

\section{RESULTS AND DISCUSSION}

Weed flora of the experimental field: Diverse weed flora was observed in an aerobic rice field at Karaikal region. Totally, 29 species of weeds from 22 genera belonging to 17 families were noticed in the experimental field during the ontogeny of aerobic rice, of which four were grasses, six were sedges, and nineteen were broad leaved. Out of these 29 species, four were perennials, and the rest were annuals (Table 1).

The grassy weeds were Echinochloa colona. Link., E. cruss-galli (L) Beauv., Leptochloa chinensis (L.) Nees. and Panicum repens. The sedges noticed were Cyperus difformis L., C. haspan L., C. iria L., C. rotundus L., Fimbristylis miliacea L. and Scirpus articulatus L.. Aeschynomene indica L., Aponogeton monostachyon L., Bergia capensis L., Cleome viscosa L., Corchorus tridents L., Eclipta alba (L.) Hassk., Glinus oppositifolius L., Hydrolea zeylanica (L.) Vahl., Lindernia crustacea, Lindernia oppositifolia, Lindernia procumbens (Krock)., Ludwigia abyssinica, L. parviflora Roxb., Marsilea quadrifolia L., Melochia corcorifolia L., Oldenlandia corymbosa L., Phyllanthus niruri L., Sphaeranthus indicus L. and Trianthema portulacastrum L. were the broad leaved weeds observed in the experimental field. The occurrence of the above weed species in aerobic rice fields have been earlier reported by Rao and Nagamani (2007), Hyderabad, Andhra Pradesh, Singh et al. (2008), Hyderabad, Andhra Pradesh, Thimmegowda et al. (2010), Mandya, Karnataka, Singh and Singh (2010), Varanasi, Uttar Pradesh, Sunil et al. (2010), Mandya, Karnataka, Ramachandiran and Balasubramanian (2012), Madurai, Tamil Nadu and Daniel et al. (2012), Karaikal, U.T. Puducherry. Tomita et al. (2003) Kyoto, Japan and Rao and Nagamani (2007) was also of the opinion that the weed flora in aerobic conditions was much diverse than those observed under flooded conditions of rice cultivation.

Weed density: During initial stages, sedges dominated $(38.3 \%)$ the experimental field (Table 2) whereas at later stages (60 DAS) broad leaved weeds were dominant $(42.5 \%)$. Grasses were found to be comparatively less dominant at both 30 DAS and 60 DAS. Of the different species of weeds, L. abyssinica $(22.0 \%$ relative density), C. difformis (19.8\% relative density) and E. colona $(17.9 \%$ relative density) were found to be the dominant weeds at seedling stage of rice. At tillering stage (60 DAS), L. abyssinica $(28.0 \%)$ among the broadleaved weeds and E. colona Link. among grasses was observed to be the most dominant weeds. $C$. 
haspan L. and S.articulates among the sedges and $C$. olitorius L., M. quadrifolia L., M. corcorifolia L., S. indicus L. and $T$. portulacastrum L. among the broad leaved weeds were observed at later stages of crop growth (90 DAS and later).

Among the grasses, E. colona Link. was the most predominant (17.9 and $28.1 \%$ at 30 and 60 DAS, respectively) followed by E. cruss-galli (L.) Beauv. (11.0 and $6.1 \%$ at 30 and 60 DAS, respectively), L. chinensis (L.) Nees. (1.2\% at $60 \mathrm{DAS})$ and P. repens L. $(0.3 \%$ at 60 DAS). However, at 30 DAS L. chinensis and $P$. repens were not noticed (Table 2). Among the sedges, C. difformis L. was the dominant weed species (19.8 and $9.7 \%$ at 30 and 60 DAS, respectively) followed by C. iria L., C. rotundus L. and F. miliaceae L. Among the broad leaved weeds, L. abyssinica was the predominant species observed at 30 and 60 DAS (22.0 and $28.0 \%$ respectively).

Weed dry weight: Grassy weeds recorded the highest dry matter accumulation (Table 3 ) at both 30 and 60 DAS (77.9 and $352.1 \mathrm{~g} \mathrm{~m}^{-2}$ ) followed by sedges (40.6 and $174.0 \mathrm{~g} \mathrm{~m}^{-2}$ ). The lowest dry weight was recorded by broadleaved weeds at both the stages (22.4 and 56.9 $\mathrm{g} \mathrm{m}^{-2}$ ) since the population of broadleaved weeds were lesser at 30 and 60 DAS. However, during later stages, at 90 DAS kinds of grass recorded higher dry matter $\left(149.0 \mathrm{~g} \mathrm{~m}^{-2}\right)$ and at 135 DAS broadleaved weeds recorded higher dry matter accumulation $\left(75.1 \mathrm{~g} \mathrm{~m}^{-2}\right)$. When the weeds were left unchecked throughout the crop season, they fully enjoyed the available resources like water, nutrients and sunlight, which resulted in higher dry matter accumulation. Several workers (Akbar et al., 2011; Khaliq et al., 2011 and Khaliq et al., 2012, Faisalabad, Pakistan and Rawat et al., 2012, Jabalpur, Madhya Pradesh) also reported that the weed dry weight was higher in unweeded control.

The Higher total dry weight of the weeds was recorded at 60 DAS $\left(583.0 \mathrm{~g} \mathrm{~m}^{-2}\right)$ followed by 90 DAS $(235.3 \mathrm{~g}$ $\mathrm{m}^{-2}$ ) whereas the total dry matter accumulation declined at maturity stage (135 DAS). Though the weed population was higher at earlier stages, the weeds completed their life cycle before the harvest of the crop.

Table 1. Weed flora observed in aerobic rice in Karaikal region.

\begin{tabular}{|c|c|c|c|c|c|}
\hline $\begin{array}{l}\text { S. } \\
\text { No. }\end{array}$ & Botanical name & Common name & Tamil name & Family & $\begin{array}{l}\text { Life } \\
\text { forms }\end{array}$ \\
\hline & Grasses & & & & \\
\hline 1. & Echinochloa colona $\mathrm{L}$ & Jungle grass & Kudiraivali & Poaceae & Annual \\
\hline 2. & Echinochloa cruss-galli $\mathrm{B}$. & Barnyard grass & Koravampul & Poaceae & Annual \\
\hline 3. & $\begin{array}{l}\text { Leptochloa chinensis (L.) } \\
\text { Nees. }\end{array}$ & Chinese sprangle top & Vakkapul & Poaceae & Annual \\
\hline \multirow[t]{2}{*}{4.} & Panicum repens $\mathrm{L}$. & Ginger grass & Ingipul & Poaceae & Perennial \\
\hline & Sedges & & & & \\
\hline 1. & Cyperus difformis $\mathrm{L}$. & Variable flat sedge & Vottakorai & Cyperaceae & Annual \\
\hline 2. & Cyperus haspan $\mathrm{L}$. & Haspan flat sedge & - & Cyperaceae & Perennial \\
\hline 3. & Cyperus iria $\mathrm{L}$. & Rice field flat sedge & Pookorai & Cyperaceae & Annual \\
\hline 4. & Cyperus rotundus $\mathrm{L}$. & Purple nut sedge & Koraikilangu & Cyperaceae & Perennial \\
\hline 5. & Fimbristylis miliacea $\mathrm{L}$. & Grass-like fimbry & - & Cyperaceae & Annual \\
\hline \multirow[t]{2}{*}{6.} & Scirpus articulatus & - & - & Cyperaceae & Annual \\
\hline & Broad leaved weeds & & & & \\
\hline 1. & Aeschynomene indica $\mathrm{L}$. & Indian jointvetch & Netti & Fabaceae & Annual \\
\hline 2. & Aponogeton monostachyon $\mathrm{L}$. & - & Kottikizhangu & Aponogetonaceae & Annual \\
\hline 3. & Bergia capensis $\mathrm{L}$ & Cape ash & Nandukalkeerai & Elatinaceae & Annual \\
\hline 4. & Cleome viscosa $\mathrm{L}$. & Tick weed & Naikkaduku & Capparidaceae & Annual \\
\hline 5. & Corchorus tridens L. & Jew's mallow & $\begin{array}{l}\text { Perumpun- } \\
\text { nakkupoondu }\end{array}$ & Tiliaceae & Annual \\
\hline 6. & Eclipta alba (L.) Hassk. & False daisy & Karisilanganni & Asteraceae & Annual \\
\hline 7. & Glinus oppositifolius L. & Bitter cumin & $\begin{array}{l}\text { Pampantra, Thura- } \\
\text { poondu }\end{array}$ & Molluginaceae & Annual \\
\hline 8. & Hydrolea zeylanica (L.) Vahl. & Ceylon hydrolea & Vellel & Hydrophyllaceae & Perennial \\
\hline 9. & Lindernia crustacea & Malaysian false pimpernel & Pitt papadi & Scrophulariaceae & Annual \\
\hline 10. & Lindernia oppositifolia & - & - & Scrophulariaceae & Annual \\
\hline 11. & $\begin{array}{l}\text { Lindernia procumbens } \\
\text { (Krock.) }\end{array}$ & Prostrate false pimpernel & - & Scrophulariaceae & Annual \\
\hline 12. & Ludwigia abyssinica & - & - & Onagraceae & Annual \\
\hline 13. & Ludwigia parviflora $\mathrm{L}$. & Water prime rose & Neerkerambu & Onagraceae & Annual \\
\hline 14. & Marsilea quadrifolia $\mathrm{L}$. & European water clover & Allakodi & Marsileceae & Perennial \\
\hline 15. & Melochia corcorifolia L. & Chocolate weed & Punnakkukirai & Sterculiaceae & Annual \\
\hline 16. & Oldenlandia corymbosa L. & Diamond flower & Kattucayaver & Rubiaceae & Annual \\
\hline 17. & Phyllanthus niruri L. & Stonebreaker & Keezhanelli & Euphorbiaceae & Annual \\
\hline 18. & Sphaeranthus indicus L. & East Indian globe thistle & Kottakaranthai & Asteraceae & Annual \\
\hline 19. & Trianthema portulacastrum $\mathrm{L}$. & Horse purslane & Saranai & Aizoaceae & Annual \\
\hline
\end{tabular}


Table 2. Absolute density and relative density of different weed species at 30 and 60 DAS.

\begin{tabular}{|c|c|c|c|c|c|}
\hline \multirow[t]{2}{*}{ S. No. } & \multirow[t]{2}{*}{ Weed species } & \multicolumn{2}{|c|}{ Absolute density (No. $\left.\mathrm{m}^{-2}\right)$} & \multicolumn{2}{|c|}{ Relative density (\%) } \\
\hline & & 30 DAS & 60 DAS & $30 \mathrm{DAS}$ & 60 DAS \\
\hline & Grasses & & & & \\
\hline 1. & Echinochloa colona $\mathrm{L}$. & 265.0 & 362.3 & 17.9 & 28.1 \\
\hline 2. & Echinochloa cruss-galli B. & 163.0 & 79.0 & 11.0 & 6.1 \\
\hline 3. & Leptochloa chinensis (L.) Nees. & 0.0 & 16.0 & 0.0 & 1.2 \\
\hline \multirow[t]{3}{*}{4.} & Panicum repens $\mathrm{L}$. & 0.0 & 4.0 & 0.0 & 0.3 \\
\hline & Total grasses & 428.0 & 461.3 & 28.9 & 35.7 \\
\hline & Sedges & & & & \\
\hline 1. & Cyperus difformis $\mathrm{L}$. & 293.0 & 125.0 & 19.8 & 9.7 \\
\hline 2. & Cyperus iria $\mathrm{L}$. & 146.7 & 108.0 & 9.9 & 8.4 \\
\hline 3. & Cyperus rotundus L. & 127.0 & 32.3 & 8.6 & 2.5 \\
\hline \multirow[t]{3}{*}{4.} & Fimbristylis miliacea $\mathrm{L}$. & 0.0 & 16.0 & 0.0 & 1.2 \\
\hline & Total sedges & 566.7 & 281.3 & 38.3 & 21.8 \\
\hline & Broad leaved weeds & & & & \\
\hline 1. & Aeschynomene indica L. & 0.0 & 24.0 & 0.0 & 1.9 \\
\hline 2. & Aponogeton monostachyon $\mathrm{L}$. & 4.0 & 12.0 & 0.3 & 0.9 \\
\hline 3. & Bergia capensis L. & 0.0 & 11.0 & 0.0 & 0.8 \\
\hline 4. & Cleome viscosa $\mathrm{L}$. & 0.0 & 17.0 & 0.0 & 1.3 \\
\hline 5. & Eclipta alba (L.) Hassk. & 8.0 & 5.0 & 0.5 & 0.4 \\
\hline 6. & Glinus oppositifolius L. & 0.0 & 6.0 & 0.0 & 0.5 \\
\hline 7. & Hydrolea zeylanica (L.) Vahl. & 0.0 & 33.0 & 0.0 & 2.6 \\
\hline 8. & Lindernia crustacea & 0.0 & 19.0 & 0.0 & 1.5 \\
\hline 9. & Lindernia oppositifolia & 8.0 & 38.0 & 0.5 & 2.9 \\
\hline 10. & Lindernia procumbens (Krock.) & 0.0 & 18.0 & 0.0 & 1.4 \\
\hline 11. & Ludwigia abyssinica & 326.4 & 361.0 & 22.0 & 28.0 \\
\hline 12. & Ludwigia parviflora L. & 132.3 & 0.0 & 8.9 & 0.0 \\
\hline 13. & Oldenlandia corymbosa $\mathrm{L}$. & 8.0 & 0.0 & 0.6 & 0.0 \\
\hline \multirow[t]{3}{*}{14.} & Phyllanthus niruri L. & 0.0 & 4.0 & 0.0 & 0.3 \\
\hline & Total broad leaved weeds & 486.7 & 548.0 & 32.9 & 42.5 \\
\hline & All weeds & 1481.4 & 1290.6 & 100.0 & 100.0 \\
\hline
\end{tabular}

Table 3. Dry matter production by weeds $\left(\mathrm{g} \mathrm{m}^{-2}\right)$ at different days after sowing in aerobic rice.

\begin{tabular}{lllll}
\hline Weed species & 30 DAS & 60 DAS & 90 DAS & 135 DAS \\
Grasses & $8.8(77.9)$ & $18.7(352.1)$ & $12.2(149.0)$ & $5.6(30.9)$ \\
Sedges & $6.4(40.6)$ & $13.0(174.0)$ & $4.3(18.2)$ & $7.6(58.3)$ \\
Broad leaved weeds & $4.6(22.4)$ & $7.6(56.9)$ & $8.2(67.9)$ & $8.7(75.1)$ \\
Total & $11.9(140.9)$ & $24.0(583.0)$ & $15.3(235.2)$ & $12.8(164.3)$ \\
\hline
\end{tabular}

Figures in the parentheses indicate original values

Thus, at harvest stage, the weed dry weight was found to be lower. This is in line with the findings of Pasha et al. (2011) who also reported lower weed dry matter production of weeds at harvest.

Growth and yield attributes of rice: The unweeded aerobic rice field registered the lowest plant height, leaf area index (LAI), dry matter production by rice and the number of tillers $\mathrm{m}^{-2}$ (Table 4 ) due to severe competition from the weeds for the resources. Mandal et al. (2011), Jabalpur Madhya Pradesh also reported that the LAI was reduced due to weed competition. Weed competition during vegetative stage greatly affects the tillers production (Mandal et al., 2011 and Micheal et al., 2013).

The unweeded aerobic rice field recorded the lowest number of tillers $\mathrm{m}^{-2}$, and the number of tillers decreased with the advance in the age of the crop. This indicated that weed competition not only reduced the number of tiller production $\mathrm{m}^{-2}$ but also increased the mortality of tillers produced. The rice dry matter pro- duction was the lowest in the weedy field due to shorter plants, lower number of leaves and tillers which in turn was due to severe competition from the weeds for the available resources. The regression analysis indicated that for every gram of dry weight produced by weeds, the rice dry matter production decreased by 1.92 grams.

Unchecked weedy aerobic rice recorded the lowest values for all yield components due to lower values of growth components which in turn was due to the lower availability of nutrients and soil moisture and higher competition from weeds for these resources.

Yield of rice: When the weeds were left unchecked, they competed with rice for all resources like nutrients, space, light and soil moisture suppressed the growth of rice which resulted in lower growth and yield attributes. Since the yield attributes were lower, the grain (333 Kg ha ${ }^{-1}$ ) and straw yields (1903 Kg ha ${ }^{-1}$ ) were also lower (Table 4). This is evident from the regression analysis which indicated that for every $\mathrm{g} \mathrm{m}^{-2}$ of 
Table 4. Growth, yield and nutrient uptake by aerobic rice under unweeded condition.

\begin{tabular}{|c|c|c|}
\hline Parameter & Values & $\begin{array}{l}\text { \% Change over } \\
\text { weed free } \\
\text { condition }\end{array}$ \\
\hline \multicolumn{3}{|l|}{ Growth attributes } \\
\hline Plant height at harvest (cm) & 64.4 & -40.9 \\
\hline Leaf Area Index at 90 DAS & 0.77 & -89.9 \\
\hline Dry matter production $\left(\mathrm{g}_{\text {plant }}{ }^{-1}\right)$ & 7.9 & -73.7 \\
\hline Number of tillers $\mathrm{m}^{-2}$ & 168.0 & -69.3 \\
\hline \multicolumn{3}{|l|}{ Yield attributes } \\
\hline Number of productive tillers $\mathrm{m}^{-2}$ & 113.3 & -77.7 \\
\hline Per cent productive tillers & 66.4 & -28.6 \\
\hline Panicle length $(\mathrm{cm})$ & 20.4 & -20.6 \\
\hline Panicle weight $(\mathrm{g})$ & 1.07 & -62.2 \\
\hline Test weight $(\mathrm{g})$ & 25.3 & -7.3 \\
\hline Number of spikelets panicle ${ }^{-1}$ & 50.0 & -51.0 \\
\hline Number of grains panicle ${ }^{-1}$ & 37.3 & -59.8 \\
\hline Filling percentage & 74.5 & -17.9 \\
\hline \multicolumn{3}{|l|}{ Yield } \\
\hline Grain yield $\left(\mathrm{Kg} \mathrm{ha}^{-1}\right)$ & 333 & -93.1 \\
\hline Straw yield $\left(\mathrm{Kg} \mathrm{ha}^{-1}\right)$ & 1903 & -77.9 \\
\hline Harvest Index & 0.15 & -58.3 \\
\hline \multicolumn{3}{|l|}{ Nutrient uptake } \\
\hline $\mathrm{N}$ uptake by rice $\left(\mathrm{Kg} \mathrm{ha}^{-1}\right)$ & 21.0 & -87.8 \\
\hline $\mathrm{P}$ uptake by rice $\left(\mathrm{Kg} \mathrm{ha}^{-1}\right)$ & 1.3 & -90.8 \\
\hline $\mathrm{K}$ uptake by rice $\left(\mathrm{Kg} \mathrm{ha}^{-1}\right)$ & 19.8 & -84.7 \\
\hline $\mathrm{N}$ removal by weeds $\left(\mathrm{Kg} \mathrm{ha}^{-1}\right)$ & 76.6 & +83.8 \\
\hline $\mathrm{P}$ removal by weeds $\left(\mathrm{Kg} \mathrm{ha}^{-1}\right)$ & 6.4 & +85.9 \\
\hline $\mathrm{K}$ removal by weeds $\left(\mathrm{Kg} \mathrm{ha}^{-1}\right)$ & 106.8 & +87.8 \\
\hline
\end{tabular}

dry matter produced by weeds, the grain yield decreased by $7.28 \mathrm{Kg} \mathrm{ha}^{-1}$ and the straw yield decreased by $10.96 \mathrm{Kg} \mathrm{ha}^{-1}$.

Nutrient uptake by rice and weeds: Unchecked weedy field recorded the lowest uptake of nutrients by rice (Table 4) due to severe competition by weeds for the available nutrients and soil moisture. This is further supported by the findings that the NPK uptake by rice had significant negative correlation with weed dry matter production and NPK depletion by weeds. Weeds, when left unchecked throughout the crop growth period, depleted $76.6 \mathrm{Kg} \mathrm{N}, 6.4 \mathrm{Kg} \mathrm{P}$ and 106.8 $\mathrm{Kg} \mathrm{K} \mathrm{ha}^{-1}$. This may be attributed to the higher density and dry matter production of weeds in the unweeded field.

\section{Conclusion}

In the experimental field of area $0.25 \mathrm{ac}$, sedges were predominant upto seedling stage (relative density $38.3 \%$ ) whereas, at later stages, broad leaved weeds were dominant $(42.5 \%)$. These weeds, when uncontrolled, competed for their resources and suppressed the performance of aerobic rice. This is evident from the lower values of all growth and yield parameters which reduced the rice yield by $93.1 \%$. Hence, an effective weed management strategy is needed to control the diverse weed flora to attain higher yield and profit under aerobic rice cultivation.

\section{REFERENCES}

Akbar, N., Ehsanullah, Jabran, K. and Ali, M.A. (2011).
Weed management improves yield and quality of direct seeded rice. Australian Journal of Crop Science, 5 (6):688-694

Bouman, B.A.M., Wang, H., Yang, X., Zhao, J. and Wang, C. (2002). Aerobic rice (Han Dao): A new way of growing rice in water-short areas. In: $12^{\text {th }}$ International Soil Conservation Organization Conference, Beijing, China. Tsinghua University Press: $175-181$

Caton, B.P., Foin, T.C. and Hill, J.E. (1997). Phenotypic plasticity of Ammania spp. competition with rice. Weed Research, (37):33-38

Chatterjee, B.N. and Maity, S. (1981). Principles and practices of rice growing, ( $2^{\text {nd }}$ Edn). Oxford and IBH Publications, New Delhi, 293

Daniel, P.S.J., Poonghzhalan, R., Mohan, R. and Suburayalu, E. (2012). Weed management for enhanced production of aerobic rice. Indian Journal of Weed Science, 44 (4):270-273

Ho, Nan-Kin and Romli, Z. (2000). Impact of direct seeding of rice cultivation: lessons from the Muda area of Malaysia. In: Proc. Workshop Direct Seeding: Research Strategies and Opportunities, 25-28 January 2000, Bangkok, Thailand.

Jackson, M.L. (1973). Soil Chemical Analysis, Ed. Prentice Hall of India Pvt. Ltd., New Delhi, 121-125

Kamoshita, A., Ikeda, H., Yamagishi, J. and Ouk, M. (2010). Ecophysiological study on weed seed banks and weeds in Cambodian paddy fields with contrasting water availability. Weed Biology and Management., 10:261-272

Khaliq, A., Matloob, A., Ahmad, N., Rasul, F. and Awan, I.U. (2012). Post emergence chemical weed control in direct seeded fine rice. J.Anim. Plant Sci., 22(4):11011106

Khaliq, A., Riaz, M.Y. and Matloob, A. (2011). Bioeconomic assessment of chemical and nonchemical weed management strategies in dry seeded fine rice (Oryza sativa). J. Plant Breed. Crop Sci., 3(12):302310

Mahajan, G., Chauhan, B.S. and Johnson, D.E. (2009). Weed management in aerobic rice in Northwestern Indo -Gangetic Plains. Journal of Crop Improvement, 23, 366-382

Maity, S.K. and Mukherjee, P.K. (2008). Integrated weed management in dry direct-seeded rainy season rice (Oryza sativa). Indian Journal of Agronomy, 53(2):116120

Mandal, D., Singh, D., Kumar, R., Kumari, A. and Kumar, V. (2011). Effects on production potential and economics of direct seeded rice sowing dates and weed management techniques. Indian Journal of Weed Science, 43(3\&4):139-144

Micheal, J.S.A.S., Juraimi, A.S., Selamat, A., Man, A., Anwar, M.P. and Uddin, M.K. (2013). Critical period of weed control in aerobic system. Australian Journal of Crop Science, 7(5):665-673

Mann, R.A., Ahmad, S., Hassan, G. and Baloch, M.S. (2007). Weed management in direct seeded rice crop. Pakistan Journal of Weed Science Research, 13(34):219-226

Pasha, L.M., Reddy, M.D., Reddy, M.G. and Devi, M.U. (2011). Effect of irrigation schedule, weed management and nitrogen levels on weed growth in rice (Oryza sativa) under aerobic conditions. Indian Journal of Weed 
Science, 43(1\&2):54-60

Ramachandiran, K. and Balasubramanian, R. (2012). Efficacy of herbicides for weed control in aerobic rice. Indian Journal of Weed Science, 44(2):118-121

Rao, A.N. and Nagamani, A. (2007). Available technologies and future research challenges for managing weeds in dry-seeded rice in India. In: $21^{\text {st }}$ Asian Pacific Weed Science Conference, 391-401

Rawat, A., Chaudhary, C.S., Upadhyaya, V.B. and Jain, V. (2012). Efficacy of bispyribac sodium on weed flora and yield of drilled rice. Indian Journal of Weed Science, 44(3): 183-185

Singh, S., Ladha, J.K., Gupta, R.K., Bhushan, L. and Rao, A.N. (2008). Weed management in aerobic rice systems under varying establishment methods. Crop Prot., 27:660-671

Singh, M. and Singh, R.P. (2010). Influence of crop establishment methods and weed management practices on yield and economics of direct-seeded rice (Oryza sativa). Indian Journal of Agronomy, 55(3): 224-229
Sipaseuth, I.P., Siyavong, P., Sihathep, V., Chanphengsay, M., Schiller, J.M., Linquist, B., Fukai, S. and Basnayake, J. (2000). Agronomic practices for improving yields of rainfed lowland rice in Laos. In: International Workshop Increased Lowland Rice Production in the Mekong Region, 30 October-2 November, Vientiane (Laos) 31-40

Sunil, C.M., Shekara, B.G., Kalyanamurthy, K.N. and Shankaralingappa, B.C. (2010). Growth and yield of aerobic rice as influenced by integrated weed management practices. Indian Journal of Weed Science, 42(3\&4):180-183

Thimmegowda, P., Murthy, K.N.K., Fathima, P.S. and Vidya, A. (2010). Studies in chemical weed control in aerobic rice (Oryza sativa L.). Crop Research, 40(1,2 \& 3):20-24

Tomita, S., Miyagawa, S., Kono, Y., Noichana, C., Inamura, T., Nagata, Y., Sributta, A. and Nawata, E. (2003). Rice yield losses by competition with weeds in rainfed paddy fields in north-east Thailand. Weed Biology and Management, 3:162-171 